\title{
PENERAPAN MEDIA VIDEO PADA PEMBELAJARAN DARING DALAM UPAYA MENINGKATKAN HASIL BELAJAR PRAKARYA KELAS 8 SMP NEGERI 10 MALANG
}

\author{
RENY SETYOWATI PRODJO \\ SMPN 10 Malang \\ e-mail: rprodjo@gmail.com
}

\begin{abstract}
ABSTRAK
Penelitian ini merupakan Penelitian Tindakan Kelas (PTK) berupa penerapan media video pada pembelajaran daring dengan tujuan meningkatkan hasil belajar Prakarya peserta didik kelompok belajar kelas 8C-D pada semester genap SMP Negeri 10 Malang tahun pelajaran 2020-2021 yang dilaksanakan dengan dua siklus dan setiap siklus tediri dari perencanaan, pelaksanaan, pengamatan, dan refleksi. Subjek penelitian pada peserta didik kelompok belajar yang memilih aspek Pengolahan kelas 8C-D SMP Negeri 10 Malang dengan jumlah peserta didik dalam penelitian ini 30 peserta didik terdiri dari 14 peserta didik kelas 8C dan 16 peserta didik kelas 8D yang tergabung dalam satu kelompok belajar yakni kelas Prakarya Pengolahan dimana satu kelas ini merupakan satu kelompok belajar peserta didik yang memilih aspek pengolahan dalam mata pelajaran Prakarya. Hasil penelitian menunjukkan bahwa penerapan dengan media video pada pembelajaran daring dapat meningkatkan hasil belajar Prakarya pada peserta didik kelompok belajar kelas 8C-D Semester Genap SMP Negeri 10 Malang. Dilihat dari awal penelitian pada tahap Pra siklus hasil belajar peserta didik yang tuntas KKM 17 peserta didik (56,7\%), dan 13 peserta didik $(43,3 \%)$ yang belum tuntas. Pada siklus I terdapat 25 peserta didik $(83,3 \%)$ yang tuntas dan 5 peserta didik $(16,7 \%)$ yang belum tuntas, dan pada siklus II terdapat 28 peserta didik $(93,3 \%)$ yang tuntas dan terdapat 2 peserta didik $(6,7 \%)$ yang belum tuntas. Dari peningkatan hasil belajar tersebut penelitian tindakan kelas ini hanya dilakukan sampai tahap siklus II karena telah mencapai kriteria ketuntasan klasikal yaitu $\geq 85 \%$ dari jumlah seluruh peserta didik tuntas belajar dan dinyatakan berhasil untuk meningkatkan hasil belajar Prakarya pada peserta didik kelompok belajar kelas 8C-D semester Genap SMP Negeri 10 Malang Tahun Pelajaran 2020/2021.
\end{abstract}

Kata Kunci: Media Video, Pembelajaran Daring, Hasil belajar.

\section{ABSTRACT}

This research is a Classroom Action Research (CAR) in the form of the application of video media in online learning with the aim of improving the learning outcomes of students in class 8C-D study groups in the even semester of SMP Negeri 10 Malang in the academic year 20202021 which is carried out in two cycles and each cycle consists of planning, implementing, observing, and reflecting. The research subjects were study group students who chose the Processing aspect of class 8C-D SMP Negeri 10 Malang with the number of students in this study 30 students consisting of 14 students in class 8C and 16 students in class 8D who joined in one study group, namely class Processing Crafts where this class is a study group of students who choose the processing aspect in the Craft subject. The results showed that the application of video media in online learning could improve the learning outcomes of Crafts learning for students in the 8C-D class even semester of SMP Negeri 10 Malang. Judging from the beginning of the research at the pre-cycle stage, the learning outcomes of students who completed the KKM were 17 students $(56.7 \%)$, and 13 students $(43.3 \%)$ who had not yet completed. In the first cycle there are 25 students $(83.3 \%)$ who have completed and 5 students (16.7\%) have not completed, and in the second cycle there are 28 students $(93.3 \%)$ who have completed and there are 2 students $(6.7 \%)$ that have not been completed. From the increase in learning outcomes, this class action research was only carried out until the second cycle stage because it had reached the classical completeness criteria, namely $85 \%$ of the total number of students who had completed learning and were declared successful in improving the craft 
learning outcomes for students in the 8C-D semester study group. Even SMP Negeri 10 Malang for the academic year 2020/2021.

Keywords: Video Media, Online Learning, Learning Outcomes.

\section{PENDAHULUAN}

Belajar harus tetap berlangsung meski pandemi belum terpasung artinya belajar tidak boleh berhenti meski masih dalam situasi pandemi saat ini yang belum berakhir di bumi Indonesia. Berdasarkan Surat Edaran Walikota Malang, Nomor 1 Tahun 2021, Tentang Pemberlakuan Pembatasan Kegiatan Untuk Pengendalian Penyebaran Corona Virus Disease 2019 (Covid 19) di Kota Malang, dengan isi edaran pada point 3 berbunyi "Melaksanakan kegiatan belajar mengajar secara daring online”, maka proses Kegiatan Belajar Mengajar di SMPN 10 Malang pada semester genap tahun pelajaran 2020-2021 belum juga dilakukan secara tatap muka, untuk menerapkan pembatasan sosial guna mencegah penyebaran virus corona, kebijakan yang diambil dengan cara menerapkan pembelajaran jarak jauh dari rumah masing-masing dengan sistem daring.

Menurut Gusty dkk (2020) " pembelajaran daring adalah upaya pembelajaran yang dilakukan dengan menggunakan jaringan internet sehingga dapat membantu para user dalam aksebilitas, konektivitas, fleksibilitas dan kemampuan untuk memunculkan berbagai jenis interaksi pembelajaran. Pembelajaran online inilah yang merupakan solusi dengan unsur pokok yang harus ada adalah sebuah jaringan internet agar semua aplikasi dapat difungsikan.

Dengan belajar sistem jarak jauh permasalahan yang muncul, kontrol guru terhadap peserta didik kurang maksimal. selain itu keterbatasan guru dalam penyampaian materi dan pemberian materi yang dikemas kurang menarik disertai dengan kurangnya guru untuk berinteraksi dengan siswa secara langsung membuat sebagian siswa kurang semangat belajar dan tidak menjamin siswa akan belajar dirumah secara optimal. Selain permasalahan tersebut permasalahan juga muncul karena kendala jaringan yang dialami oleh peserta didik, karena tidak semua peserta didik dirumah tersedia fasilitas jaringan yang stabil. Dengan pembelajaran daring memungkinkan juga terjadinya loss kontak antara peserta didik dan guru dengan berbagai alasan, ini terbukti dari peserta didik tidak semuanya aktif mengikuti saat jam pembelajaran berlangsung. Pada situasi yang demikian, seorang pendidik dituntut juga untuk kreatif dalam penyampaian materi, sehingga memberikan kesan pada peserta didik serta menciptakan komunikasi antar peserta didik, dan menjadikan peserta didik lebih aktif saat proses pembelajaran. Rustiyarso (2020) menyatakan guru harus banyak berlatih mengaplikasikan berbagai tindakan alternatif guna memperbaiki proses belajar dikelas dapat berupa penggunaan model /metode/strategi/pendekatan pembelajaran tertentu yang disesuaikan persoalan.

Penulis yang sekaligus sebagai guru dalam penelitian ini memilih menggunakan media pembelajaran untuk mengatasi permasalahan pada saat pembelajaran daring. Media merupakan bagian yang tak terpisahkan untuk memudahkan serta mewujudkan tercapainya pemahaman materi kepada peserta didik. Media diartikan sebagai perantara antara pengirim pesan yang berfungsi sebagai sumber atau resources dan penerima informasi atau receiver. Media dalam proses belajar berperan dalam menjembatani proses penyampaian dan pengiriman pesan dan informasi (Benny A P :2017). Dengan pemilihan media video mempunyai harapan peserta didik lebih tertarik menyimak materi, sehingga dapat mencapai tujuan pembelajaran berupa ketuntasan pada hasil belajar. Secara sederhana, yang dimaksud dengan hasil belajar merupakan kemampuan yang diperoleh peserta didik setelah melalui kegiatan belajar. Faktor yang mempengaruhi keberhasilan belajar peserta didik dibagi menjadi dua yaitu faktor eksternal dan faktor internal (Parnawi , 2019). Penggunaan media video dapat meningkatkan hasil belajar, pernyataan ini didukung dari hasil penelitian terdahulu yang pernah dilakukan ( Novita dkk: 2019) mengungkapkan bahwa "terdapat pengaruh positif dan signifikan antara penggunaan media pembelajaran audio visual Video terhadap Hasil Belajar pada SD”. Dengan bahan rujukan ini maka penulis perlu penelitian lanjutan. 
Fakta dilapangan hasil penilaian harian yang dilaksanakan pada bulan Januari 2021 awal semester genap tahun 2020-2021, masih banyak peserta didik nilainya di bawah 75, angka ini merupakan batas nilai terendah dari KKM yang dinyatakan tuntas. Data awal pada penelitian ini diperolah dari 30 peserta didik , ada 17 peserta didik tuntas $(56,7 \%)$ dan 13 peserta didik tidak tuntas $(43,3 \%)$. Rendahnya persentase peserta didik yang mencapai Kriteria Ketuntasan Minimal (KKM) menunjukkan bahwa ketuntasan hasil belajar peserta didik secara klasikal masih belum optimal sehingga perlu ditingkatkan.

Berdasarkan rujukan dan fakta dilapangan di atas, maka rumusan masalah yang diangkat dalam penelitian ini sebagai berikut: "Apakah penggunaan media video pada pembelajaran Daring dapat meningkatkan hasil belajar Prakarya pada peserta didik kelompok belajar kelas 8C-D Semester Genap SMP Negeri 10 Malang tahun pelajaran 2020/2021?".

Adapun tujuan penelitian ini adalah untuk mengetahui penerapan media video pada pembelajaran Daring dalam meningkatkan hasil belajar Prakarya pada peserta didik kelompok belajar kelas 8C-D yang memilih aspek Pengolahan Semester Genap SMP Negeri 10 Malang tahun pelajaran 2020/2021.

\section{METODE PENELITIAN}

Tindakan pada penelitian ini dirancang dengan menggunakan media video pada pembelajaran daring untuk meningkatkan hasil belajar peserta didik kelompok belajar kelas 8C-D Semester Genap SMP Negeri 10 Malang dengan jumlah 30 peserta didik. Langkah penelitian mengikuti model penelitian Targart. yaitu planning perencanaan, acting (tindakan), observing (pengamatan), dan reflecting (refleksi) yang di gambarkan sebagai berikut :

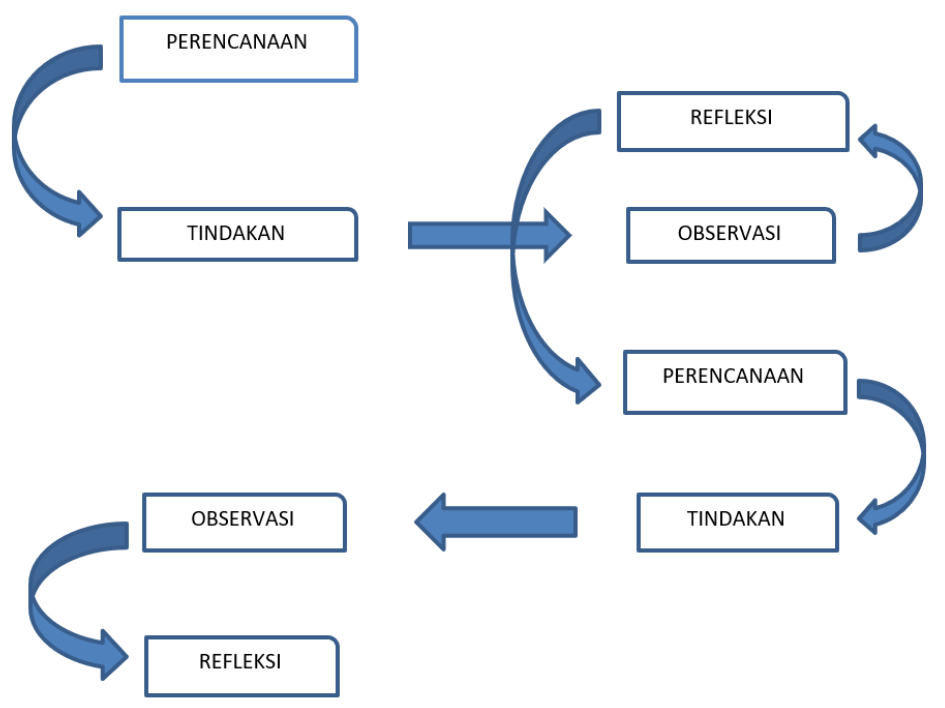

Gambar 1 : Model Penelitian Targart dan Kemmis

(Parnawi , 2020)

Teknik yang digunakan dalam pengumpulan data sebagai berikut :

1. Wawancara

Wawancara dilakukan untuk mencari informasi data dalam proses pembelajaran. Wawancara dilakukan kepada guru, peserta didik, dan fasilitator yang berkolaborasi untuk memperoleh data atau informasi yang lebih terperinci guna melengkapi data hasil pengamatan. Wawancara yang dilakukan dalam penelitian ini adalah mewawancarai rekan guru maupun wali kelas 8 SMP Negeri 10 Malang. Melalui wawancara peneliti mendapat data mengenai model pembelajaran dan media yang sering digunakan guru dalam proses pembelajaran pada saat pandemi ini, selanjutnya sebagai bahan diskusi untuk menganalisis media yang efektif untuk pembelajaran. 
2. Observasi

Observasi digunakan untuk mengamati kegiatan proses pembelajaran dengan media Video pada pembelajaran daring kelompok belajar kelas 8C-D Semester genap. Observasi dilakukan secara online dengan mengamati keaktifan peserta didik dalam mengikuti proses pembelajaran dari meet secara virtual, absensi maupun tugas yang dikirim peserta didik di GCR serta selalu komunikasi dengan wali kelas maupun rekan guru.

3. Tes Tertulis.

Tes adalah sejumlah pertanyaan yang disampaikan pada seseorang atau sejumlah orang untuk mengungkapkan keadaan atau tingkat perkembangan salah satu atau beberapa aspek psikologi di dalam dirinya.Tes tertulis dilakukan terhadap peserta didik untuk mengetahui hasil belajar Prakarya pada masa pembelajaran Daring kelompok belajar kelas 8C-D semester genap SMP Negeri 10 Malang.

4. Dokumentasi.

Dokumentasi dalam penelitian ini sebagai bukti melaksanakan proses kegiatan pembelajaran dan bukti peserta didik mengerjakan tugas yang diberikan guru melalui media video dalam pembelajaran Daring. Analisis data dilakukan setelah data terkumpul selanjutnya dalam PTK ini digunakan analisis kuantitatif yang diperoleh dari penilaian harian berupa persentase dengan rumus :

$$
P=\frac{\text { jumlah siswa tuntas belajar }}{\text { jumlah seluruh siswa }} \times 100 \%
$$

Kategori pencapaian hasil belajar dinyatakan "TUNTAS" jika nilai $\geq$ KKM 75 . “BELUM TUNTAS" < KKM 75. Ketuntasan klasikal $\geq 85$.

\section{HASIL DAN PEMBAHASAN}

Hasil

Data hasil Penelitian Tindakan Kelas berupa Hasil Belajar Peserta Didik yang dilaksanakan dalam 2 siklus penelitian. Masing-masing siklus terdiri dari 4 tahap yaitu perencanaan, pelaksanaan, pengamatan, dan refleksi. Sebelum siklus dilaksanakan dilakukan masa Pra Siklus untuk memperoleh data awal.

Deskripsi Data Hasil Penelitian sebagai berikut:

1. Deskripsi Pra Siklus.

Tahap Pra Siklus dilakukan sebelum peneliti melaksanakan Siklus I pada bulan Januari 2021 sampai Pebruari 2021 minggu ke-1, dengan materi "Bahan Pangan Setengah jadi dari Serealia, Kacang-kacangan dan Umbi “. Hasil dari observasi Pra Siklus terdapat masalah pembelajaran. Adapun nilai hasil penilaian harian Pra Siklus dapat di lihat pada Tabel berikut:

Tabel 1. Hasil Belajar Peserta Didik Pra Siklus

\begin{tabular}{|c|c|c|c|}
\hline NO & Hasil Belajar & Jumlah Peserta Didik & Persentase \\
\hline 1 & Tuntas & 17 & $56,7 \%$ \\
\hline 2 & Belum Tuntas & 13 & $43,3 \%$ \\
\hline 3 & Rata-rata nilai & \multicolumn{2}{|c|}{72,9} \\
\hline
\end{tabular}




\section{HASIL BELAJAR PRASIKLUS}

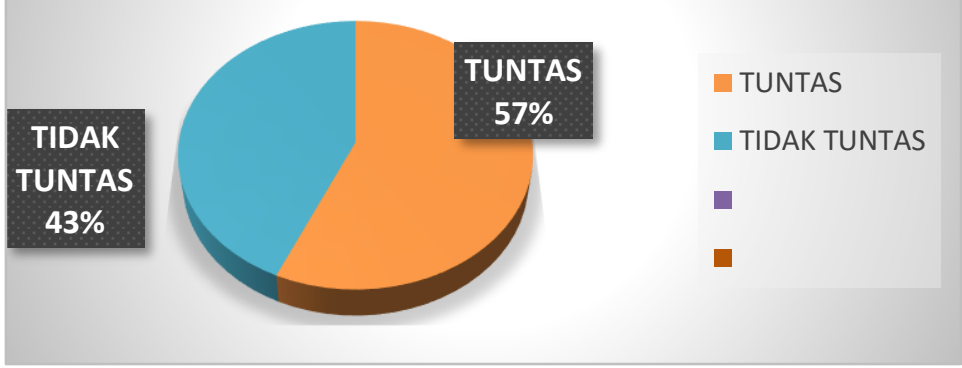

\section{Gambar 2. Diagram Ketuntasan Hasil Belajar Pra siklus}

Berdasarkan data diatas peserta didik yang tuntas ( mencapai KKM) ada 17 peserta didik $(56,7 \%)$, sedangkan yang belum tuntas ada 13 peserta didik (43,3\%). Secara klasikal pada siklus ini belum tuntas belajar, karena peserta didik yang memperoleh nilai $\geq 75$ (nilai KKM) hanya mencapai $56,7 \%$ dari peserta didik keseluruhan. Hasil presentase belum mencapai kriteria ketuntasan klasikal yaitu $\geq 85 \%$.

\section{Diskripsi Siklus I.}

Berikut nilai hasil belajar Siklus I yang diambil dari penilaian harian dengan materi "Hidangan dari Bahan Pangan Setengah Jadi Serealia, Kacang-kacangan, Umbi Dan Teknik Pengolahannya".

Tabel 2. Hasil Belajar Peserta Didik Siklus I

\begin{tabular}{|c|c|c|c|}
\hline NO & Hasil Belajar & Jumlah Peserta Didik & Persentase \\
\hline 1 & Tuntas & 25 & $83,3 \%$ \\
\hline 2 & Belum Tuntas & 5 & $16,7 \%$ \\
\hline 3 & Rata-rata Nilai & \multicolumn{2}{|c}{81,5} \\
\hline
\end{tabular}

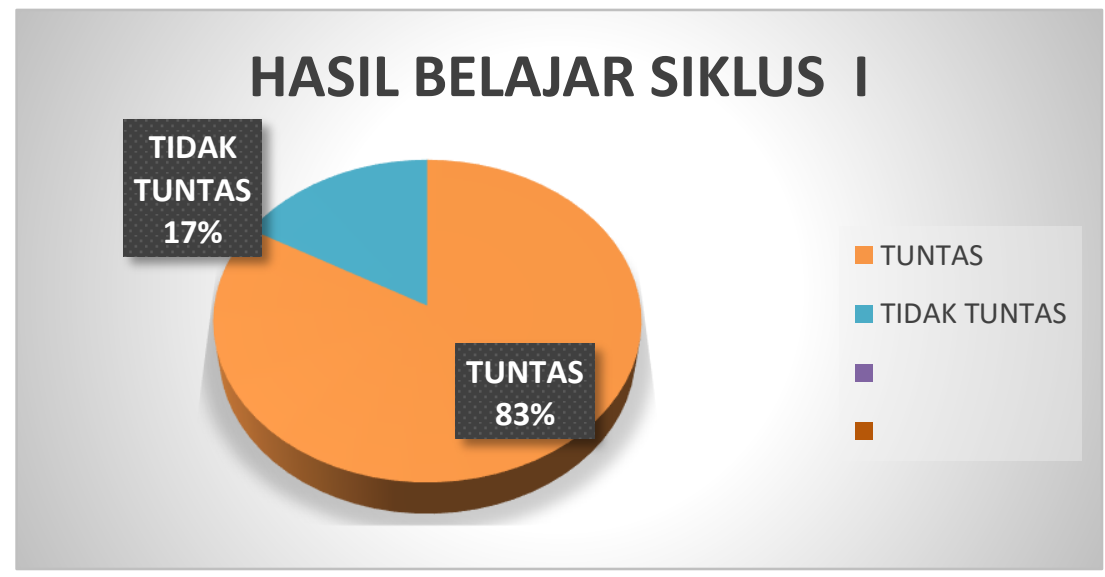

Gambar 3. Diagram Ketuntasan Hasil Belajar Siklus I

Pada Siklus I peserta didik yang tuntas mencapai KKM sejumlah 25 peserta didik $(83,3 \%)$, sedangkan yang belum tuntas ada 5 peserta didik (16,7\%). Secara klasikal pada siklus ini belum tuntas belajar, karena siswa yang memperoleh nilai $\geq 75$ (nilai KKM) hanya mencapai 83,3\% dari siswa keseluruhan. Hasil presentase belum mencapai kriteria ketuntasan klasikal yaitu $\geq 85 \%$ dari jumlah seluruh peserta didik yang tuntas belajar, maka harus dilaksanakan Siklus selanjutnya yaitu Siklus II. 


\section{Diskripsi Siklus II}

Penelitian pada siklus II dengan materi Penyajian Dan Pengemasan. Berikut nilai hasil belajar Siklus II.

Tabel 3. Hasil Belajar Peserta Didik Siklus II

\begin{tabular}{|c|c|c|c|}
\hline NO & Hasil Belajar & Jumlah Peserta Didik & Persentase \\
\hline 1 & Tuntas & 28 & $93,3 \%$ \\
\hline 2 & Belum Tuntas & 2 & $6,7 \%$ \\
\hline 3 & Rata-rata Nilai & \multicolumn{2}{|c|}{$\mathbf{8 4 , 9}$} \\
\hline
\end{tabular}

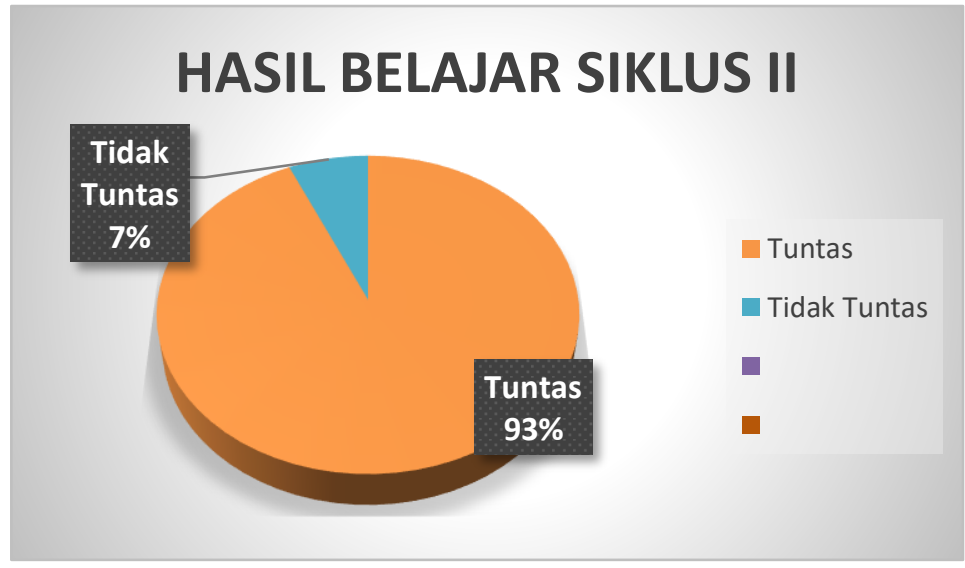

\section{Gambar 4. Diagram Ketuntasan Hasil Belajar Peserta didik Siklus II}

Hasil penelitian pada siklus II, peserta didik yang tuntas ( mencapai KKM) ada 28 peserta didik $(93,3 \%)$, sedangkan yang belum tuntas ada 2 peserta didik $(6,7 \%)$. Pada Siklus 2 pembelajaran sudah tuntas secara klasikal karena pada siklus ini peserta didik yang memperoleh nilai $\geq 75$ (nilai KKM) sudah mencapai kriteria ketuntasan klasikal yaitu $\geq 85 \%$. Berikut diagram ketuntasan pada Siklus II.

Dari tiga tahapan yang sudah dilakukan, , secara keseluruhan dapat kita lihat pada tabel rekapitulasi hasil penelitian berikut ini :

Tabel 4. Rekapitulasi Hasil Belajar peserta didik

\begin{tabular}{|l|c|c|c|c|c|c|}
\hline \multicolumn{1}{|c|}{ Hasil Belajar } & \multicolumn{2}{c|}{ Pra Siklus } & \multicolumn{2}{c|}{ Siklus I } & \multicolumn{2}{c|}{ Siklus II } \\
\hline Rata-rata nilai & \multicolumn{2}{|c|}{72,9} & \multicolumn{2}{c|}{81,5} & \multicolumn{2}{c|}{84,9} \\
\hline Tuntas & 17 & $56,7 \%$ & 25 & $83,3 \%$ & 28 & $93,3 \%$ \\
\hline Belum Tuntas & 13 & $43,3 \%$ & 5 & $16,7 \%$ & 2 & $6,7 \%$ \\
\hline
\end{tabular}

\section{Pembahasan}

Berdasarkan tabel rekapitulasi hasil belajar peserta didik pada penelitian ini perolehan nilai rata-rata hasil belajar peserta didik dari Pra Siklus 72,9 menjadi 81,5 pada siklus I, selanjutnya pada siklus II menjadi 84,9 , artinya menunjukan sebuah peningkatan pada nilai rata-rata kelas. Berikut dapat digambarkan Grafik Nilai Rata-Rata Kelas. 


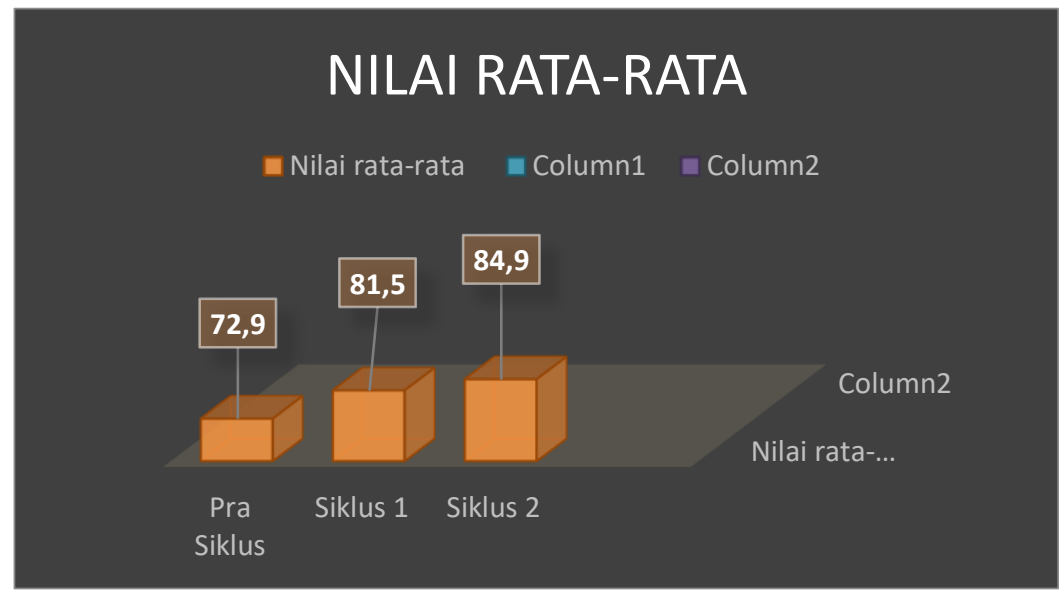

\section{Gambar 5. Grafik Nilai Rata-rata Hasil Belajar Peserta Didik}

Dilihat proses pembelajaran yang dilakukan dengan menggunakan media video pada pembelajaran daring, menunjukan bahwa hasil pembelajaran Pra Siklus dengan nilai rata-rata 72,9 terdapat 17 peserta didik $(56,7 \%)$ dinyatakan tuntas, dan 13 peserta didik (43,3\%) tidak tuntas,. Hasil tersebut belum memenuhi kriteria ketuntasan yang telah ditetapkan, maka dilakukan penelitian pada Siklus I.

Hasil pembelajaran Siklus I mengalami peningkatan yaitu 25 peserta didik $(83,3 \%)$ tuntas, dan 5 peserta didik $(16,7 \%)$ tidak tuntas, dengan nilai rata-rata 81,5. Hasil tersebut belum memenuhi kriteria ketuntasan secara klasikal yang telah ditetapkan yaitu $\geq 85 \%$, maka harus dilakukan penelitian pada Siklus II dengan materi dan waktu berbeda. Pada Siklus II terdapat 28 peserta didik $(93,3 \%)$ tuntas, dan 2 peserta didik $(6,7 \%)$ tidak tuntas dengan nilai rata-rata 84,9. Berikut perkembangan ketuntasan belajar digambarkan pada grafik dibawah ini.

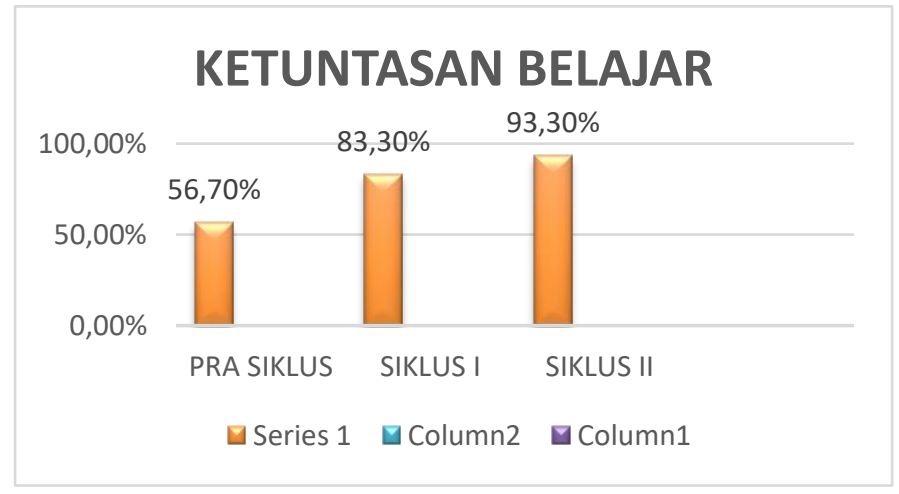

Gambar 6: Grafik ketuntasan Belajar

Berdasarkan grafik ketuntasan belajar. Peningkatan ketuntasan belajar dari Pra Siklus ke Siklus I sebesar 26,6\%, dan Siklus I ke Siklus II sebesar 10\%. Dengan demikian hasil penelitian diyatakan penggunaan media video pada pembelajaran daring dapat meningkatkan hasil belajar Prakarya kelompok belajar kelas 8C-D semester genap SMP Negeri 10 Malang Tahun Pelajaran 2020/2021. Pernyataan ini didukung dari hasil penelitian terdahulu yang pernah dilakukan ( Novita dkk: 2019) mengungkapkan bahwa "terdapat pengaruh positif dan signifikan antara penggunaan media pembelajaran audio visual Video terhadap Hasil Belajar pada SD".Selain itu juga diperkuat oleh Khairani dkk (2019) dalam jurnalnya yang berjudul "Studi Meta Analisis Pengaruh Video Pembelajaran Terhadap Hasil Belajar Peserta Didik" dalam simpulannya : media pembelajaran video dapat mememudahkan bagi para pendidik dalam melakukan kegiatan belajar. Video pembelajaran yang dapat digunakan dan dapat dibuka kapanpun bagi peserta didik sehingga dapat meningkatkan hasil belajar bagi peserta didik. 


\section{KESIMPULAN}

Hasil penelitian dapat disimpulkan bahwa "penggunaan media video pada pembelajaran daring dapat meningkatkan hasil belajar Prakarya Kelompok Belajar kelas 8CD Semester Genap SMP Negeri 10 Malang”. Dapat dibuktikan dengan data peningkatan hasil belajar sebagai berikut :

1. Pra Siklus terdapat 17 peserta Didik $(56,7 \%)$ tuntas, dan 13 peserta didik $(43,3 \%)$ tidak tuntas dengan nilai rata-rata 72,9 .

2. Siklus I terdapat 25 peserta didik $(83,3 \%)$ tuntas, dan 5 siswa $(16,7 \%)$ tidak tuntas dengan nilai rata-rata 81,5 .

3. Siklus II terdapat 28 peserta didik tuntas $(93,3 \%)$ tuntas, dan peserta didik $(6,7 \%)$ tidak tuntas dengan nilai rata-rata 84,9.

4. Peningkatan ketuntasan belajar dari Pra Siklus ke Siklus I sebesar 26,6\%, dan Siklus I ke Siklus II sebesar $10 \%$.

\section{DAFTAR PUSTAKA}

Gusti Sri dkk. 2020. Belajar Mandiri Pembelajaran Daring ditengah Pandemi Covid 19. Yayasan kita menulis.

Khairani Miftahul, Sutisna, Suyanto Slamet. 2019.Studi Meta Analisis Pengaruh Video Pembelajaran Terhadap Hasil Belejar Peserta Didik. Jurnal Biolokus vol 2 No 1 Januari - Juni 2019. 158-166

Novita Lina , Sukmanasa Elly, Mahesa Yudistira Pratama 2019. Penggunaan Media Pembelajaran Video Terhadap Hasil Belajar Siswa SD. Indonesian Journal of Primary Education, Vol 3, No 2 64-72

Parnawi A. 2019. Psikologi Belajar, Yogyakarta : Cv Budi Utama

Parnawi A. 2020. Penelitian Tindakan Kelas .Yogyakarta. Deepublish CV Budi Utama Pribadi Benny A. 2017. Media dan Teknologi dalam Pembelajaran. Jakarta : Kencana Rustiyarso, Wijaya Tri. 2020.Panduan dan Aplikasi Penelitian Tindakan Kelas. Yogyakarta : Noktah. 